\title{
The Korean War Prisoners Who Chose Neutral Nations: An Introduction
}

\author{
David Cheng Chang \\ Associate Professor, Division of Humanities, Hong Kong University of \\ Science and Technology, Hong Kong \\ changcheng@ust.hk
}

\begin{abstract}
At the end of the Korean War, 76 Korean and 12 Chinese prisoners of war (POWs) refused to return to either side of their divided countries. Instead, they sought asylum in neutral nations that were yet to be determined. Situating this theme issue's three articles in the larger Korean War historiography, this introduction provides a chronology of major events that culminated in the 88 pows' departure from Korea and voyage to India on 9 February 1954. Emphasizing that these 88 men were not fundamentally different from the other 150,00o Korean and 21,00o Chinese Pows, this paper underscores the fact that these 88 Pows, having survived battles and captivity, risked their lives to escaped from their compound leaders and sought neutral nations' protection. The stories of the 88 prisoners "choosing" neutral nations were in fact tales of survival and escape.
\end{abstract}

\section{Keywords}

Korean war - prisoners of war - neutral nations - India - Latin America

The Korean War broke out seventy years ago, resulting in three years of mass destruction and killing. More than 36,ooo Americans, 180,00o Chinese, and millions of North and South Koreans were killed in the war. Unlike the official and popular remembrance of World War II, commemorations of the Korean War in the United States mostly have been muted; it is no different this year. Nevertheless, scholars of the war may disagree with this popular notion of the "Forgotten War," pointing to the fact that various aspects of the conflict have received extensive study, especially since the $1990 \mathrm{os}$ 
Upon close examination, however, it is clear that much of the scholarship still focuses on the origins and the first year of the war and relies heavily on official diplomatic, political, and military sources. While the prisoners of war (POW) issue is invariably identified as the central bone of contention in the second half of the war, this part of the conflict has received limited attention, and even less for its central players-the prisoners. Western scholarship on Korean War pows consists mostly of political history relying on U.S. diplomatic and military documents, while the Chinese and Korean prisoners themselves remain nameless, faceless, and characterless masses. ${ }^{1}$

Only in recent years did scholars begin to give more focus to the prisoners themselves. Sheila Miyoshi Jager discusses a Republic of Korea (Rок) POW's captivity in the north and his post-repatriation hardship in South Korea. Tessa Morris-Suzuki examines the experience of the only Japanese POW in the Korean War, who previously had fought in the Sino-Japanese War and the Chinese Civil War. ${ }^{2}$ The North Korean and Chinese prisoners' voices, however, are still largely missing. Perhaps the first scholarly interview of any North Korean POW was Bruce Cumings's meeting with double-amputee Pak Chang-uk in P'yŏngyang in $1987 .^{3}$ Also in the late 1980s, Pulitzer Prizewinning writer and historian John Toland interviewed dozens of Chinese and North Korean pows, including Zhang Zeshi and Chu Yŏng-ok, probably the most articulate and prolific Chinese and North Korean prisoners respectively. 4

After a nearly two-decade hiatus, there is a recent surge in scholarly works that put pows front and center in examining the Korean War. In Interrogation Rooms of The Korean War: The Untold History, Monica Kim makes full use of oral history interviews with surviving North Korean prisoners and Japanese-American interrogators, prisoners' memoirs, and Toland's interview notes stored at the Franklin

1 Major works focusing on the prisoner of war (POW) issue include Barton J. Bernstein, "The Struggle over the Korean Armistice: Prisoners of Repatriation," in Child of Conflict: The Korean-American Relationship, 1945-1953, Bruce Cumings, ed. (Seattle: University of Washington Press, 1983), 261-307; Rosemary Foot, A Substitute for Victory: The Politics of Peacemaking at the Korean Armistice Talks (Ithaca, NY: Cornell University Press, 199o); Charles S. Young, Name, Rank, and Serial Number: Exploiting Korean War POWs at Home and Abroad (New York: Oxford University Press, 2014). For other works that contain chapters on the issue, see Callum A. MacDonald, Korea: The War Before Vietnam (New York: Free Press, 1986); William Stueck, The Korean War: An International History (Princeton, NJ: Princeton University Press, 1995).

2 Sheila Miyoshi Jager, Brothers at War: The Unending Conflict in Korea (New York: Norton, 2013), 226-36; Tessa Morris-Suzuki, "Prisoner Number 6oo,oo1: Rethinking Japan, China, and the Korean War 1950-1953," Journal of Asian Studies 74, no. 2 (May 2015): 411-32.

3 Bruce Cumings, The Korean War: A History (New York: Modern Library, 2010), 76.

4 John Toland, In Mortal Combat: Korea, 1950-1953 (New York: William Morrow, 1991). 
D. Roosevelt Presidential Library. ${ }^{5}$ In The Hijacked War: The Story of Chinese POWs in the Korean War, this author draws on interviews with more than eighty Chinese POWs and one North Korean prisoner to demonstrate how the U.S. government's policies of voluntary repatriation and prisoner reindoctrination backfired, enabling Chinese anti-Communist prisoners and Chiang Kai-shek to hijack the armistice negotiations' agenda and nearly doubled the length of the war. ${ }^{6}$

Curiously, in South Korea, there has been little scholarship on former North Korean Pows, who progressive intellectuals largely have shunned as fanatic anti-Communists. However, thanks to the enormous influence of Ch'oe In-hun's novel The Square (1960), many South Koreans have idealized the 76 Korean prisoners who chose neutral nations as independent, high-minded intellectuals who rejected "the Cold War regime" in search for alternatives. In 2016, when this author first told Jung Keun Sik, a sociologist at Seoul National University, and Jung Byung Joon, a historian at Ewha Womans University, about his interview with North Korean Pow Kim Kwan-ok in Argentina, they immediately decided to embark on this collaborative research project. Two trips to Buenos Aires and São Paulo followed, where they interviewed six North Korean Pows and one Chinese prisoner in 2016 and 2017. Jung Keun Sik conducted follow-up interviews with Im Kwan-taik in Seoul and Kŏje Island when the São Paulobased Im visited South Korea in 2018.

Their findings have come as a great surprise. As Jung Byung Joon's article "The Political Was Personal: Shifting Images of 76 Korean Pows Who Went to Neutral Nations" shows, the 76 prisoners' choice of neutral nations was personal rather than ideological in nature. Jung's interview with Ch'oe In-hun, one year before his death, confirms that Ch'oe wrote the novel without any detailed knowledge about the 76 prisoners. His article provides an excellent overview of the 76 Korean prisoners' motivations in rejecting both North and South Korea and opting to settle in a neutral nation, and their variegated experiences in India, Argentina, and Brazil. In his article titled "Survival Strategies of a Korean War Prisoner Who Chose Neutral Nations: A Study Based on Im Kwan-taik's Oral History and Documents," Jung Keun Sik examines Im's survival strategies from teenage years as a bereaved child of revolutionary in P'yŏngyang, to his experiences in battle and captivity, to his days in India and Brazil, and to his recent transformation into the leader among the few surviving pows in Brazil.

5 Monica Kim, Interrogation Rooms of The Korean War: The Untold History (Princeton, NJ: Princeton University Press, 2019).

6 David Cheng Chang, The Hijacked War: The Story of Chinese POWs in the Korean War (Stanford, CA: Stanford University Press, 2020). 


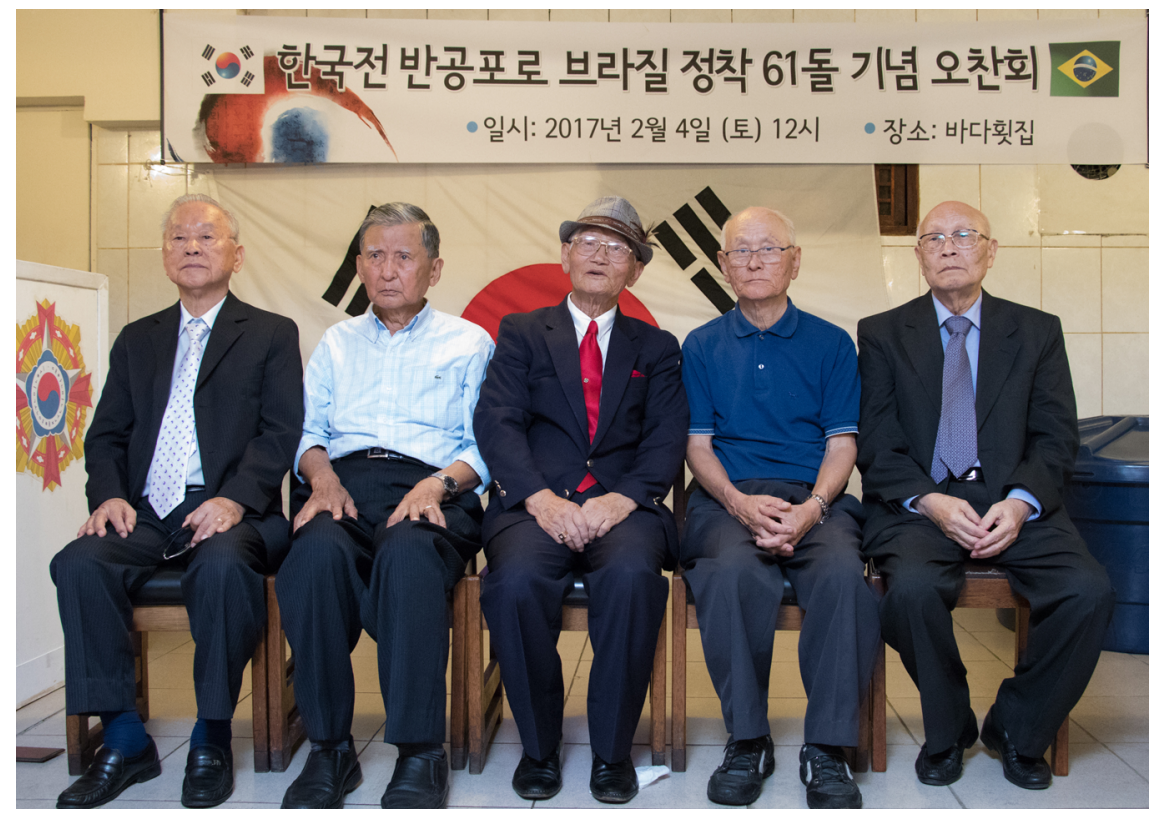

FIGURE 1 Five surviving North Korean POWs commemorate the 61st anniversary of their settlement in Brazil and Argentina, 4 February 2017. From left to right: Yi Jun-hi, Mun Myŭng-chol, Im Kwan-taik, Yi Eung-yong, Kim Kwan-ok. Photo credit: David Cheng Chang.

Lee Sunwoo contributes the third article in this theme issue. She is a doctoral candidate at Ewha University, who has been studying the 76 Pows since her years working at the Roк Diplomatic Archives. In "Ideology Was A Uniform to BeTaken On and Off: An Anti-Communist Prisoner's Survival from Manchuria to Korea to India," Lee seeks to answer one baffling question. Why did Chi Ki-ch'ŏl, one of the most important North Korean anti-Communist Pow leaders, in the end choose to go to neutral nations instead of staying in South Korea? To solve this puzzle, Lee contends, one has to understand Chi's complex life history.

On the following pages, this introduction provides a chronology of major events that culminated in the 76 Korean and twelve Chinese Pows' departure from Korea and voyage to India on 9 February 1954. What cannot receive enough emphasis is that throughout the Korean War and the months following the armistice, neither the United Nations nor the United States ever formally offered prisoners the option to go to a neutral nation. There was no legal basis for such a right nor actual mechanism to facilitate such a choice. There was no democratic, peaceful procedure where prisoners were afforded the choice. Had that been the case, the number of prisoners choosing neutral nations almost certainly would have been in the tens of thousands instead of 88 . 


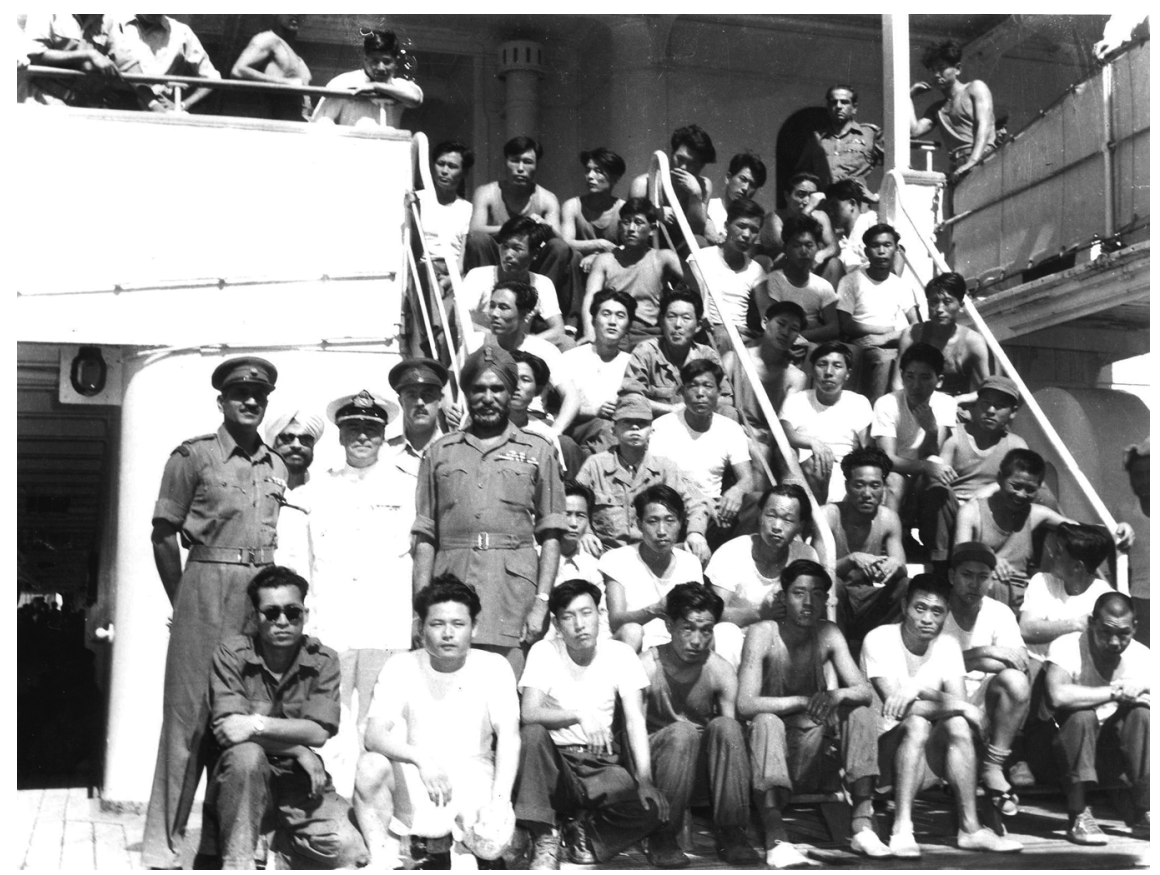

FIGURE 2 Some of the 88 Prisoners of War choosing neutral nations and Custodial Force Indian military officers en rout to India, February 1954. National Institute of Korean History.

The 76 Korean and twelve Chinese Pows were not fundamentally different from the other 150,00o Korean and 21,000 Chinese POWs. Thanks to accident, contingency, luck, and their own nerve, they had survived battles and prison, and they seized the final opportunity to escape from the iron clutches of their compound leaders. They sought personal protection and asylum in a neutral nation. As the following pages will show, "choice" is probably a misnomer; "desperate escape" is more accurate. The stories of the 88 prisoners "choosing" neutral nations were in fact tales of escape and survival.

The Pow repatriation issue was fraught with tension from the outset. The definitions of people as North Koreans or South Koreans were artificial concepts resulting from the partition of the peninsula that the United States and the Soviet Union imposed at the end of World War II. Further complicating the definitions was the evolving and sometimes arbitrary interpretation of the United Nations Command (UNC). Shortly before the two sides exchanged prisoner rosters at P'anmunjŏm on 18 December 1951, the UNC reclassified 37,000 out of nearly 150,000 Korean prisoners as "civilian internees," initially defined as South Korean residents who were "impressed into North Korean military units from civilian life" and "innocent bystanders" accidentally swept into POW camps. As the UNC 
continued to loosen the standard and reclassified other categories of prisoners as "civilian internees" and released them, by the time of the armistice on 27 July 1953, the UNC had reduced the total number of North Korean prisoners to 83,723. Among them were 75,823 repatriates, who the UNC exchanged in August and September 1953. More than 7,900 non-repatriates, who were supposedly anti-Communists, refused to return north, including Chi Ki-ch'ŏl and Im Kwan-taik. A final decision on the latter's fate would not occur until January and February $1954{ }^{7}$

Although both Chi and Im were born in southern Korea, their pre-war connections with North Korea were so deep that the UNC never classified them as "civilian internees." Using Chi's UNC interrogations records and his oral history interview records preserved in the National Institute of Korean History, Lee Sunwoo precisely delineates Chi's complex pre-Korean War trajectory. Chi was born in Kyŏngsang-bukto in 1923, but in 1926 his entire family moved to a town near Mukden (Shenyang) in Manchuria. After finishing elementary school, he worked to support his family. The Japanese Kwantung Army drafted him in August 1944, but Chi was lucky to see no combat, as his unit withdrew to Kyushu shortly before the Soviet invasion of Manchuria on 9 August 1945. Within two weeks after Japan's surrender on 15 August, some 80o,ooo out of the 2.16 million Koreans in Manchuria returned to Korea. ${ }^{8}$ Chi, however, traveled in the opposite direction, returning from Japan through the Korean peninsula to Manchuria. He soon volunteered to join the Korean Volunteers Army (KVA) under the aegis of the Chinese Communist Party.

Chi later claimed that he joined the KVA to spare his brothers from military service, but the historian Kim Donggil argues that the Chinese Communists' policy of allocating land to Korean settlers, in sharp contrast to the Nationalist policy of land confiscation and discrimination, generated substantial support among the Koreans in Manchuria, which might have contributed to Chi's decision. ${ }^{8}$ Chi's KVA unit later became the Chinese People's Liberation Army (PLA) 166th Division, which was composed mostly of ethnic Koreans and under the command of Pang Ho-san, another member of the Yan'an faction. After fighting the four-year Chinese Civil War, the PLA transferred the 164th Division and 166th Divisions, to North Korea in July 1949 and the two units reorganized into the Korean People's Army (KPA) 5th and 6th Divisions respectively. The timelines Chi provided in his interrogations and oral history interviews are remarkably accurate when compared to scholarly research. ${ }^{10}$

7 Walter G. Hermes, Truce Tent and Fighting Front (Washington, DC: U.S. Government Printing Office, 1966), 138, 141-42, 514-15.

8 Kim Donggil, "The Chinese Civil War and the Ethnogenesis of the Korean Minority in Northeast China," Chinese Historical Review 21, no. 2 (November 2014): 122.

9 Ibid., p. 130.

10 Ibid., pp. 121-42. 
Im Kwan-taik's history was probably even more extraordinary, so much so that it raises methodological challenges regarding the assessment of archival documents and oral history accounts. While Chi's interrogation records and oral history accounts are largely consistent, Im, when Jung Keun Sik first interviewed him, repudiated much of his interrogation records. Further complicating the matter, in his second interview with Jung, Im revealed new information that is sometimes at odds with what he had told in the first interview. To reconcile differences between the UNCs interrogation records of Im in $195^{\circ}$ and two rounds of multi-session oral history interviews that he conducted in 2017 and 2018 , Jung conducted field interviews with residents near the 38 th parallel. The result is a largely plausible reconstruction of Im's history.

A year after Im Kwan-taik's birth in Ch'ungch'onng Province in 1928, his father Im P'yŏng, an independence activist and a student leader, fled into exile in Manchuria. In 1935, his mother heard that Im P'yŏng was studying at the Whampoa Military Academy in Nanjing, the capital of the Chinese Nationalist government. She took Kwan-taik to reunite with his father. When the Sino-Japanese War broke out in 1937, she and Kwan-taik returned to Korea. Im P'yŏng later split from the Chinese Nationalists and joined the Chinese Communists. He became the commissar of the and Detachment of the KVA, which was under the leadership of the Korean Communists' Yan'an faction. While his unit fought the Japanese in North China in 1942, he died of typhoid at the age of 34. The Chinese and Korean Communists mourned him as a hero."

After Korea's liberation and division in August 1945, Im P'yŏng's former comrades, now major leaders in North Korea, arranged for Im Kwan-taik's secret passage to P'yŏngyang in 1946. Im studied in the Red Flag Man'gyŏngdae School for the Bereaved Children of Revolutionaries, Kim Il Sung University, and Sadong Military Academy. In early 1949, the North Korean government dispatched him to Moscow for military and security training. Unsurprisingly, Im told his UNC interrogators none of the above information. Much of the details never had been known until Jung Keun Sik's in-depth interviews. As Jung's article shows, one in fact can corroborate the major events in Im's seemingly fantastic stories with a close reading of the history of the Korean Communists, especially the Yan'an faction. Fellow Yan'an faction leader Yi Sang-jo later became a negotiator at P'anmunjŏm and eventually North Korea's ambassador to Moscow. Mu Chŏng, the KVA commander in China, soon led the attack across the 38 th parallel on 25 June 1950. Im's recollections significantly enrich existing understanding of the complex origins and evolution of the Korean Communist movements in China and both Koreas.

11 Jiefang Ribao [Liberation Daily], 27 August 1942, p. 2. 
When the Korean War broke out, both Chi, an artillery battalion commander, and Im, a political officer, served in the KPA 6th Division that spearheaded the attack on Kaesong, Seoul, and then all the way to the Pusan Perimeter. The Rodong Sinmun [Workers' Newspaper], the North Korean government mouthpiece, featured Chi as a hero. When KPA leadership ordered his unit to withdraw after MacArthur's Inch'ŏn landing, however, Chi deserted and surrendered to American troops. As Lee Sunwoo observes, Chi "had little difficulty with switching allegiances whether in the Japanese Kwantung Army, the Chinese PLA, or North Korea's KPA." Now he voluntarily surrendered, claiming to be an anti-Communist defector. To his great surprise, however, the UNC treated him as a regular Pow, not a defector who they would be obliged to embrace and protect.

Im's war experience was much murkier. To avoid further Counter Intelligence Corps (CIC) interrogation, he lied to his captors to hide his privileged background in North Korea, downplaying his rank and role. He apparently succeeded, as the Nisei interrogator considered him "very cooperative" and his information "fairly reliable." When Jung interviewed him, however, Im disputed nearly all key data in his interrogation reports, most notably his rank, activities, and date of capture. Instead of being a junior lieutenant, he claimed to be a lieutenant colonel. He asserted he was captured on 17 November $195^{\circ}$ in Yŏju, not on the 1oth in Yŏngdŭng-po. While it is most unlikely to come to a definitive conclusion, it is possible that in the final chaotic days of the KPA collapse, Im might have received appointment to a higher than usual rank. His capture below the 38th parallel in November, more than forty days after the UNC had advanced above the parallel, does raise some questions. Im claimed that when his unit withdrew to Kimhwa, General Mu Chŏng ordered it to return south, apparently as a guerrilla unit. Jung's recent fieldwork and interviews with elderly residents near the parallel confirm North Korean guerrilla activities under UNC occupation. Moreover, when compared to the fourteen months that the Chinese 18oth Division's commissar Wu Chengde and his guards spent hiding in the mountains near the parallel after the Fifth Offensive debacle in May 1951, forty days behind the enemy lines is nothing extraordinary. ${ }^{12}$ Im's seemingly fantastic account was plausible.

During the interrogation process, CIC officials assessed Chi as "intelligent but uncooperative" and "arrogant." Having dreamed of a brotherly welcome, he vehemently protested his treatment as a pow, but to no avail. After his transfer to Pusan, he quickly ingratiated himself with sympathetic RoK officers and won appointment as the officers' compound representative. He

12 Chang, The Hijacked War, pp. 174-75. 
informed on Communist prisoners digging escape tunnels. Consequently, the UNC camp officials transferred him to a separate compound for anti-Communist pows. In contrast, Im pretended to be cooperative, successfully deceiving his interrogators. A pattern of hiding his identity and past would persist throughout his three-year-and-three-months captivity. He was interned in Compound 66, the officers' compound, known as "one of the first, most fanatic, and most openly Communist-controlled on Koje-do."13 Claiming to be a student before the war, which was technically true, Im did not hold any position of power in the compound. However, Communist Pow leaders tasked him with teaching Marxism and the history of the Bolshevik Party to fellow prisoners. He recalled that prisoners made knives and other weapons in preparation for a prison break. General Mark W. Clark, the UNC commander, recalls in his memoir an incident in November 1951 when a suspected anti-Communist Pow was tortured to death in the compound. ${ }^{14}$ Apparently his experience in the compound still traumatizing him, Im, when Jung accompanied him to revisit Kŏje Island in 2018, merely said he "had difficulties eating and sleeping."

In April and May 1952, the UNC carried out a massive screening of Korean and Chinese Pows to identify those who would violently resist repatriation, thereby segregating the pro- and anti-Communist Pows. While all compounds that the anti-Communists controlled cooperated, including the two large Chinese compounds, 72 and 86, those Communist-controlled compounds, including the 66, refused cooperation. On 7 May, Korean prisoners in Compound 76 kidnapped the prison commandant Brigadier General Francis T. Dodd. Only after Dodd's successor, Brigadier General Haydon L. Boatner, used overwhelming force to break up Compound 76 on 10 June did other compounds comply with dissolution and movement to smaller enclosures. ${ }^{15}$ Im's Compound 66 was the last defiant Communist stronghold. Canadian guards reported a steady hammering inside the tents, suggesting prisoners were forging weapons. ${ }^{16}$ Nevertheless, UNC forces moved the compound peacefully on 13 June. ${ }^{17}$

Even though Compound 66 and other Communist-controlled compounds complied with the breakup and transfer, their prisoners did not go through the

13 William C. Bradbury, Samuel M. Meyers, and Albert D. Biderman, eds., Mass Behavior in Battle and Captivity: The Communist Soldier in the Korean War (Chicago: University of Chicago Press, 1968), 310.

14 Mark W. Clark, From the Danube to the Yalu (New York: Harper, 1954), 62.

15 Chang, The Hijacked War, pp. 241-82; Kim, The Interrogation Room, pp. 171-210.

16 Washington Post, 12 June 1952, p. 6.

17 Ted Barris, Deadlock in Korea: Canadians at War, 1950-1953 (Toronto: Macmillan Canada, 1999), 167. 
screening process. Unless they made the daring escape from the unyielding control of their comrades during the move, the UNC automatically classified them as repatriates. Communist prisoners tortured and even killed those suspected of defection. Clearly, Im Kwan-taik did not have the chance to make a choice. The UNC transferred him, along with other presumably pro-Communist repatriates, to the neighboring Yongch'o Island. Fearing future punishment for losing battles and being captured, Im eventually decided to extricate himself from the Communist camp. To do so, he first had to feign illness to leave the compound and then, more critically, to inform on fellow prisoners who were digging escape tunnels. This act of betrayal, which led to his former comrades' arrest, but certified his status as an anti-Communist, continues to pain Im to this day, as Jung's article shows.

After the screening of prisoners and the breakup of large prison compounds from April to June 1952, the UNC finally segregated pro- and anti-Communist prisoners. It transferred some 20,000 Chinese prisoners to two separate camps on Cheju Island. The UNC kept pro-Communist, pro-repatriation Korean prisoners on Kŏje and its neighboring islands, including Yongch'o. It moved anti-Communist, non-repatriate Korean prisoners to the main peninsula. After his defection, Im relocated from Yongch'o to Pusan. He had reached a point of no return. There were other non-repatriate prisoners, however, who would escape his fate. In the summer and fall of 1952, the UNC unilaterally released some 38,000 "civilian internees," who it now broadly defined as any anti-Communist prisoner whose residence was south of the 38 th parallel prior to 25 June $1950 .{ }^{18}$ Neither Chi nor Im qualified. They remained imprisoned along with some 35,00o Korean non-repatriate Pows.

The sudden death of Soviet Premier Joseph Stalin on 5 March 1953 and his successors' peace initiatives quickly led to the resumption of the P'anmunjŏm truce talks that the UNC had adjourned in October 1952. After the speedy exchange of sick and wounded Pows in April and May, the United States brushed aside Rок opposition and signed the Terms of Reference on prisoner exchange with the Communist side on 8 June, thus overcoming the final obstacle to an armistice agreement. In an attempt to sabotage the imminent armistice, President Syngman Rhee ordered Rok guards to open the prison gates and let loose anti-Communist Korean prisoners on the early morning of 18 June 1953. More than 27,00o Korean and 63 Chinese prisoners managed to escape. As Jung explains, Im reluctantly left his camp, but soon the U.S. guards intervened and opened fire, killing many. Im escaped death, but was recaptured. Chi also escaped, but soon a U.S. search squad captured him. They 
became two of the last 7,900 anti-Communist Korean prisoners remaining in UNC custody ${ }^{19}$

Despite Rhee's obstructionism, the belligerents signed the armistice agreement on 27 July 1953. Prisoner exchanges ensued. The UNC repatriated 70,183 Korean and 5,640 Chinese Pows in August and early September. What hung in the balance was the fate of 7,900 Korean and 14,704 Chinese anti-Communist non-repatriates, who had dominated the armistice negotiations agenda for almost a year and a half. ${ }^{20}$ They were to face another six months of tribulation, during which they had to make potentially life-and-death decisions. Governing this process was the most consequential part of the armistice agreement - the Terms of Reference for the Neutral Nations Repatriation Commission (NNRC), which the negotiators agreed upon on 8 June to resolve the impasse over non-repatriate prisoners.

In essence, the Chinese Communists in the Terms of Reference accepted the principle of voluntary repatriation - the policy they had bitterly resisted for 18 months - under the guise of a face-saving procedure, which entailed ninety days of "explanation" for non-repatriation prisoners under the custody of the NNRC at P'anmunjŏm. Item 8 defines the process as follows:

The Neutral Nations Repatriation Commission, after having received and taken into custody all those prisoners of war who have not exercised their right to be repatriated, shall immediately make arrangements so that within ninety (9o) days after the Neutral Nations Repatriation Commission takes over the custody, the nations to which the prisoners of war belong shall have freedom and facilities to send representatives to the locations where such prisoners of war are in custody to explain to all the prisoners of war depending upon these nations their rights and to inform them of any matters relating to their return to their homelands, particularly of their full freedom to return home to lead a peaceful life, under the following provisions .... ${ }^{21}$

The approximately 22,000 Chinese and Korean non-repatriates, although Western media usually referred to them as "anti-Communist pows," the Terms of Reference identify them as "prisoners who have not exercised their right to be repatriated." The keyword is repatriation. Monica Kim astutely points

The numbers are a calculation from the statistics in U.S. Army Military History Office, The Handling of Prisoners of War During the Korean War (San Francisco, CA: Headquarters, U.S. Army, Pacific, 1960), 74; Hermes, Truce Tent and Fighting Front, p. 515. The number of Chinese escapees is from Chang, The Hijacked War, p. 327.

20 Hermes, Truce Tent and Fighting Front, pp. 514-15.

$21 \quad$ Quoted in ibid., p. 534. 


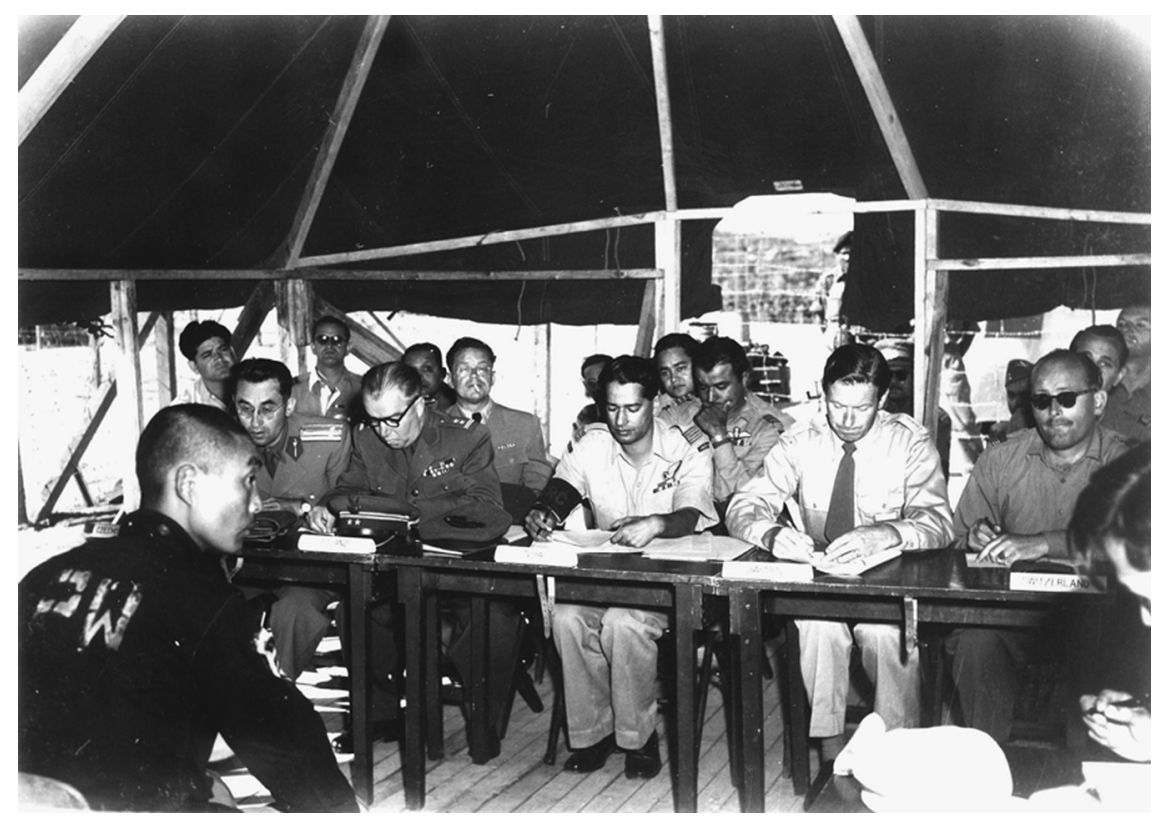

FIGURE 3 A Korean prisoner of war speaking to the Neutral National Repatriation Commission subcommittee in the explanation booth. National Institute of Korean History.

out that the entire proceedings at P'anmunjŏm "hinged on one concept: repatriation." As she explains, the individual prisoner, during his interview in the "explanation rooms," must decide "through which door he or she would exitthe door for repatriation, or the door for nonrepatriation." ${ }^{22}$

What cannot receive enough emphasis is that the Terms of Reference did not formally offer prisoners the third choice of going to a neutral country. It makes no formal provision for choosing neutral nations in the explanation process. As a detailed sketch of the "explanation room" shows, there was no third door for choosing neutral nations. ${ }^{23}$

The Terms of Reference does mention, however, when the NNRC ceases its function 120 days after it first assumes custody of the prisoners, it had thirty days to help individual prisoners to apply for asylum in neutral nations. After completion of the explanations, "according to the application of each individual, those who choose to go to neutral nations shall be assisted by the Neutral Nations Repatriation Commission and the Red Cross Society of India," item 11 stipulates. "This operation shall be completed within thirty (30) days, and

22 Kim, The Interrogation Room, p. 270.

23 Ibid., p. 273. 


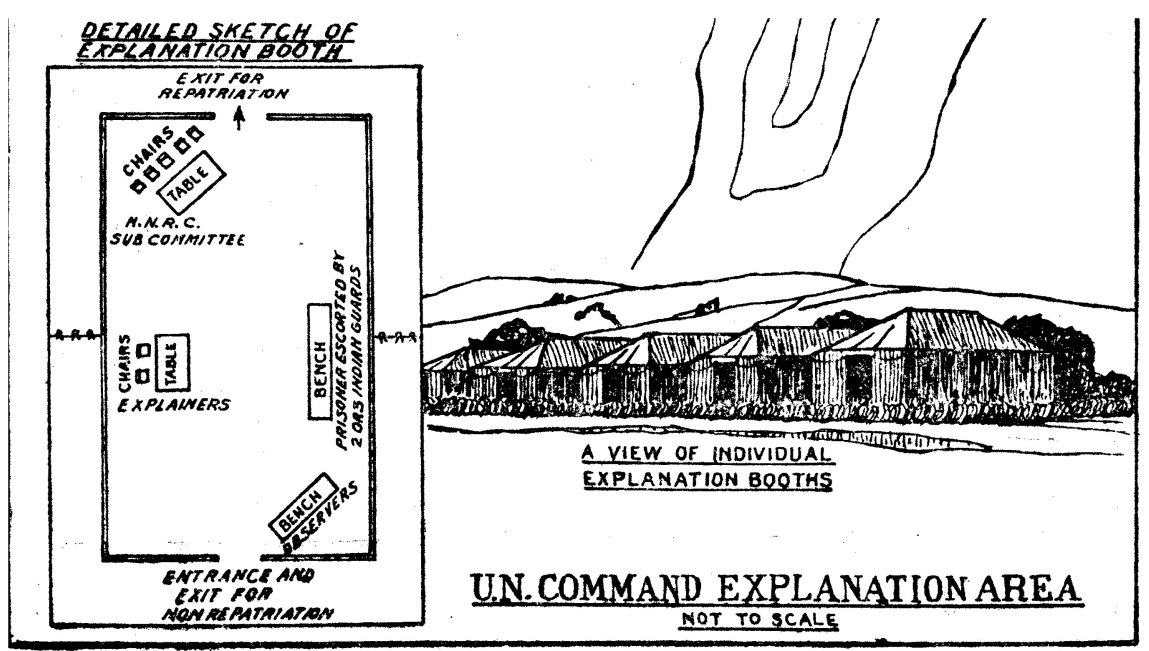

FIGURE 4 "Detailed Sketch of Explanation Booth" from S. N. Prasad, History of the Custodian Force (India) in Korea, 1953-54 (New Delhi, India: Historical Section, Ministry of Defence, 1976).

upon its completion, the Neutral Nations Repatriation Commission shall immediately cease its functions and declare its dissolution." 24

That is to say, at the end of the entire process, prisoners individually could ask NNRC officials or its Custodian Force India (CFI) guards for asylum, provided they knew this particular provision in the Terms of References and had direct access to N NRC officials or Indian guards. These are extremely high bars for the prisoners, who were mostly illiterates living in camps under the tight control of anti-Communist leaders and their henchmen.

As it turned out, when the ninety-day explanation period expired on 23 December, explanations took place for only ten days. Thanks to anti-Communist prisoners' organized effort to derail the process and prevent fellow prisoners from choosing repatriation, only 3,500, or fifteen percent, of the 22,000 Chinese and Korean prisoners went through the explanation proceedings. Less than 150 interviewees, or slightly more than four percent of the 3,500, asked for repatriation. "This was a much smaller number than the total who sought repatriation by escape from the compounds," observed Indian General Kodendera Thimayya, the NNRC chairman. ${ }^{25}$

Im was one of the 3,500 prisoners who received an explanation. Although his late father's friend General Yi Sang-jo was the North Korean representative

24 Quoted in Hermes, Truce Tent and Fighting Front, p. 535.

25 Kodendera S. Thimayya, Experiment in Neutrality (New Delhi: Vision Books, 1981), 189-9o. 
liaising with the NNRC, the North Korean explainers did not know his identity. He recalled that he refused repatriation and went through the third door for neutral nations. As discussed earlier, there was no third door in the explanation tent. Perhaps, Im did ask to go to a neutral country at the end of his session, even though there was no physical third door. Or perhaps he conflated his choice made on a later occasion with events during the explanation.

As Thimayya noted, more prisoners escaped from the compounds and sought repatriation than those who made the choice during the explanation proceedings. It is also true for those Pows who chose neutral nations. "Choosing neutrality usually did not occur in the space of the explanation room, although occasionally a pow did choose a 'neutral country' at the end of his explanation," Monica Kim observes. "More often than not, the choice of a 'neutral country' happened in these moments of rather desperate escape."26

Kim Kwan-ok, an anti-Communist leader, recounted his explanation and escape experiences to the author in 2014 and 2017. When he entered the explanation tent, the KPA representative pointed to the door to the north and waxed poetic: "This road leads to light; the other leads to the devils." "The road you're pointing to leads to the devils. And the other leads to light," Kim retorted. "I'll walk the other road." He returned to his anti-Communist compound. However, Kim later used his privilege as security chief to approach the main gate. He spoke to a Japanese-speaking Indian guard and asked to go to neutral nations. ${ }^{27}$

Thanks to his leadership position, Kim Kwan-ok's surprise defection from fellow anti-Communists may seem simple. But for most other prisoners, the escape could be nerve-racking. Chu Yŏng-bok, the Manchurian-born polyglot and former KPA interpreter, had come under suspicion of wishing to go to a neutral nation. Compound leaders constantly monitored and frequently interrogated and tortured him. On 14 January 1954, 22 days after the end of explanations and eight days before the UNCs planned release of non-repatriates to South Korea, Chu made a sudden mad dash for the perimeter fence and climbed over it. When an Indian soldier pulled him down, Chu recalled, "I felt a comfort rise up from a mysterious place deep inside of me."28 Similarly, the one-time Chinese anti-Communist leader Cheng Liren scaled the barbed wire fence before dawn to seek Indian protection. Had he attempted the escape later that day, other prisoners would have stopped him, Cheng feared. ${ }^{29}$

\footnotetext{
26 Kim, The Interrogation Room, p. 291.

27 Author and Lee Peihua's interview with Kim Kwan-ok, 15 October 2014, Buenos Aires, Argentina; Author and Lee Sunwoo's interview with Kim Kwan-ok, 6 February 2017, São Paulo, Brazil. See also, Chang, The Hijacked War, pp. 335, 338.

28 Kim, The Interrogation Room, p. 292.

29 Chang, The Hijacked War, p. 338.
} 
When Im Kwan-taik entered the special enclosure for prisoners choosing neutral nations, he was shocked to see Chi Ki-ch'ǒl was already there. How could Chi, the infamous anti-Communist leader who Im believed had tortured and killed fellow prisoners for wanting to go to a neutral nation, choose neutral nations himself? This is the puzzle that Im, other Pows, and the three authors in this theme issue all seek to answer. Chi enjoyed the distinction of the Rodong Sinmun celebrating him as a hero and the Renmin Ribao [People's Daily], the Chinese Communist mouthpiece, vilifying him as a "murderer." As Lee Sunwoo and Jung Byung Joon demonstrate, Chi was probably the second most important anti-Communist Pow leader, who "closely collaborated with the RoK intelligence and army to sabotage the 'explanation' process." Lee also found evidence of Chi spying on fellow POWs and providing their photographs to ROK diplomats in India.

Although the Armistice Agreement specifies that 22 January 1954 was the last day that the NNRC had legal custody over non-repatriate prisoners, the commission returned two days ahead of schedule 14,220 Chinese and 7,574 North Korean prisoners to the UNC, which immediately transferred them to the governments of Taiwan and South Korea. ${ }^{30}$ However, 104 Chinese and Korean POWs had sought the NNRCs protection and expressed the wish to go to neutral nations. As Jung Byung Joon shows, ironically, their most common desired "neutral nation" was none other than the United States. As a U.S. State Department report reveals, 65 prisoners requested transit to the United States. Some of them alleged that "they were promised this right during captivity and have produced at least one propaganda leaflet ... saying that the U.S. would accept 5,00o PWs who would desert the Commie cause and come to our side." Some also asked to go to Sweden or Switzerland. ${ }^{31}$ Unsurprisingly, all such requests were rejected. The fact that not a single country made a clear commitment to accept these prisoners only compounded the uncertainty. As a result, fifteen North Korean Pows who wanted to go to the United States decided to stay in South Korea. The NNRC turned them over on 4 February. ${ }^{32}$

When the some 6,ooo Custodian Forces India troops departed Korea on 9 February 1954, the 74 North Korean, two South Korean, and twelve Chinese pows went along as if by default, as no other country had committed to receiving them. These three articles provide fascinating details on the Indian

\footnotetext{
$30 \quad$ Ibid., p. 4.

31 Everett F. Drumright to Robert J. G. McClurkin, 3 February 1954, folder 1, Korean Black Book, February 1-17, 1954, Records Of The Bureau of Far Eastern Affairs Relating To Southeast Asia, and The Geneva Conference, 1954, Office of Southeast Asian Affairs, Records of the U.S Department of State, Record Group 59, National Archives II [hereafter NAII], College Park, MD.

New York Times, 5 February 1954, p. 4.
} 


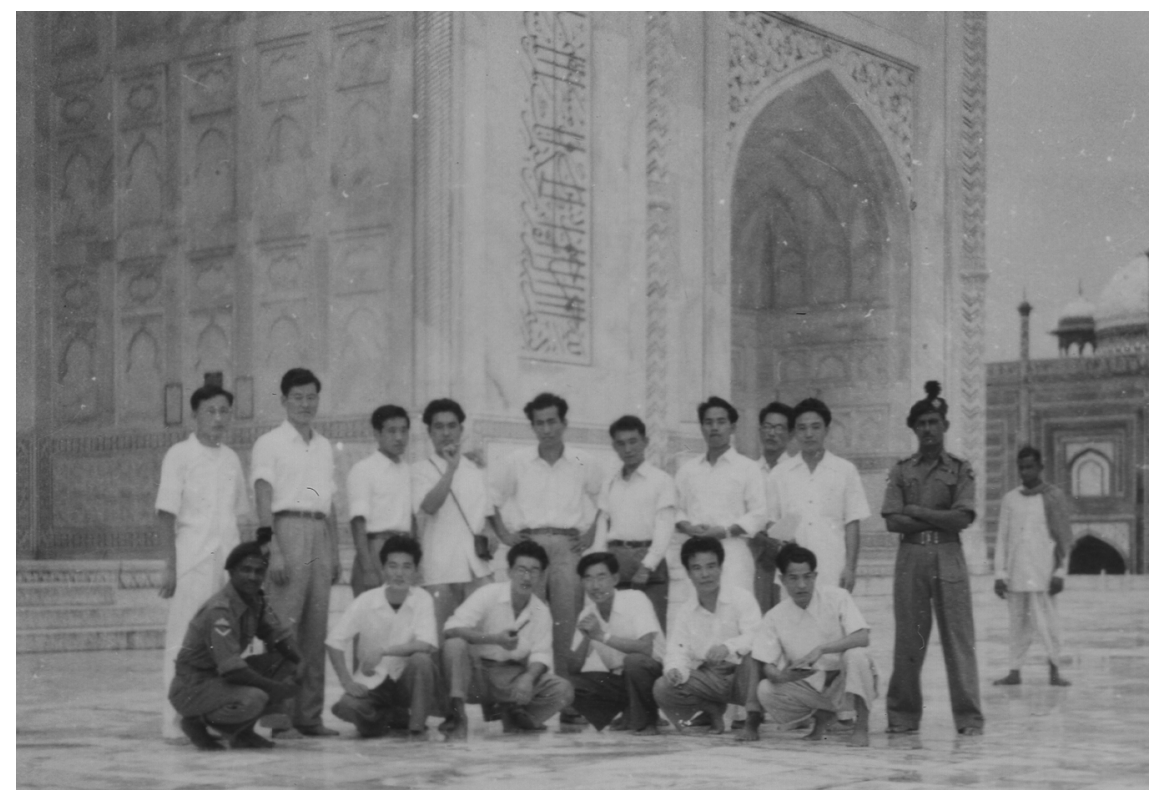

FIGURE 5 A group of Korean and Chinese former prisoners of war at the Taj Mahal in the summer of 1954. Chi stands in the center of the second row. Courtesy of Cheng Liren.

government's reception of the prisoners, the Korean Pows' internal divisions and conflicts, their persisting efforts to go to other neutral nations, and their divergent experiences in Argentina, Brazil, and India.

As the chart below summarizes, six Korean prisoners returned to North Korea, 49 went to Brazil, twelve went to Argentina, and nine stayed in India. The most surprising case was the arch-anti-Communist Chi Ki-ch'ŏl, who literally was stuck in India, a country he dismissed as pro-Communist. As Lee Sunwoo demonstrates, Chi's preferred neutral nation was Mexico, which he saw as a stepping-stone to the United States, "the ultimate anti-Communist nation." Why did Mexico, Brazil, and Argentina refuse to accept Chi? Monica Kim discovered Chi's and his friend Hyŏn Dong-hwa's petition letters in the United Nations Archives, which sought to prove they were bona fide anti-Communists. ${ }^{33}$ The real reason for these countries' rejection of Chi was not his lack of anti-Communist credentials, but probably the opposite. Jung Byung Joon suggests that rejection of Chi and several others occurred precisely because of their extreme anti-communism. Jung Keun Sik offers a more specific reason-a secret informer's report, which perhaps accused Chi of committing atrocities in UNC POW camps.

33 Kim, The Interrogation Room, p. 297. 
North Korea

People's Republic of China (PRC)

Brazil

Argentina

India
6

$\begin{array}{rr} & 2 \\ 49 & 6 \\ 12 & 2 \\ 9 & 2\end{array}$

TABLE 1

The Final Disposition of the 76 Korean and Twelve Chinese Pows, as of 1958 .

Cheng Liren, the leader of the twelve Chinese Pows in India, developed a close bond with Chi, the leader of the 76 Koreans. When interviewed, Cheng recalled the tense relationship that existed between Chi and the Indian government, which saw Chi as a "troublemaker." ${ }^{34}$ A U.S. State Department report shows that barely a year after Prime Minister Jawaharlal Nehru personally welcomed the 88 prisoners to India, a number of them camped before his house on 17 March 1955, spent a night on the lawn of the Japanese embassy, and on the next morning "were forcibly returned to camp." India arrested their leader, none other than Major Chi, and then released him on May 24. ${ }^{35}$ However, as Lee's article shows, Chi claimed that his release came after only three days. Despite his frustrations, Chi survived and thrived in India as a successful businessman, profiting from trade between India and South Korea, as Lee's article describes. No doubt, Chi was the ultimate survivor.

While the three articles in this volume focus on the fate of the 76 Korean prisoners, the fate of the twelve Chinese warrant a few words. In short, two returned to China, six went to Brazil, two went to Argentina, and two remained in India. A little more than two months after the 88 Pows' arrival in India, the Indian government transferred Chinese prisoner Li Chaozhu to the Chinese embassy on 31 May 1954. Li claimed that anti-Communist trusties had tormented and intimidated him in UNC POW camps in Korea. When he "accidentally" heard about the possibility to go to a neutral nation, he asked the Indian guards for asylum. Once in India, he wrote to the Chinese embassy requesting repatriation. ${ }^{36}$ Within a few months, another Chinese prisoner Sun Tai Yoo returned to the People's Republic of China (PRC). ${ }^{37}$

\footnotetext{
34 Author's interview with Cheng Liren, 16 October 2014, Buenos Aires, Argentina.

35 Embassy New Delhi to Department of State, 25 May 1955, 695A.oo24/5-2555, RG 59, NAII.

$36 \quad$ Neibu Cankao [Internal Reference], 5 June 1951, pp. 84-85.

37 "Chinese Opting for People's Republic of China," information taken from letter of 24 January 1955, Miscellany-Correspondence and reports concerning the Neutral Nations Repatriation Commission, S-oo18-ooo6-35, United Nations Archives, New York, NY.
} 


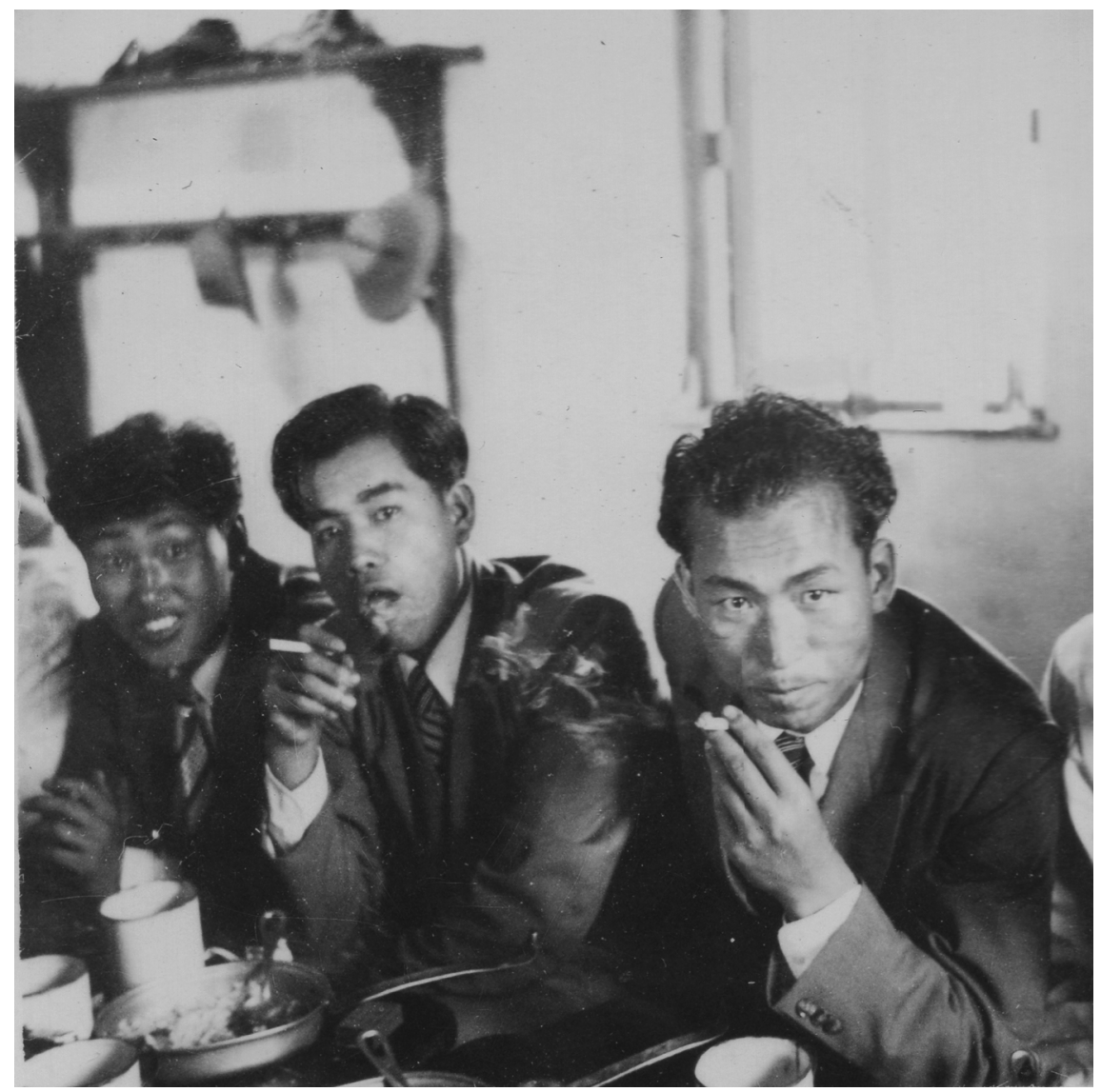

FIGURE 6 Chi Ki-ch'ǒl (right) and Cheng Liren (center) in India in either 1954 or 1955. Courtesy of Cheng Liren.

In February 1956, 55 Korean and Chinese prisoners went to Brazil. While some reports provide the nationality breakdown as fifty Koreans and five Chinese, Lee Sunwoo has discovered that U Ek-wo, a Manchurian-born prisoner who the UNC had listed as Chinese, the NNRC counted as one of the fifty Koreans. ${ }^{38}$ Using local Brazilian newspapers and oral history interviews with the children of a deceased Chinese prisoner, Leonardo Barbosa has identified three Chinese-Liao Weirong (Liu Wei Yong), Pan Guirong (Pan Kou Young), and Yang Rongsheng (Yang Yoong Sheong). Born in a landlord family, Liao went

38 Lee Sunwoo, "Han'gukchŏnjaenggi Chungnipkuk Sŏnt’aek P'oroŭi Palsaenggwa Sŏnggyŏk” ["The Characteristics and Arrangement of the Prisoners of War Who Chose to Go to Neutral Countries During the Korean War"], Yŏksa wa Hyŏnsil [Quarterly Review of Korean History], no. 90 (December 2013): 355 . 
to college. After taking power in 1949, the Communists executed his parents in a public square. He joined the PLA as a private and went to Korea, where he was injured and captured. ${ }^{39}$ While Liao's decision may seem baffling, in reality it might be the only viable option for a landlord's son to save his life and redeem himself in Communist New China, as fellow prisoners' histories attest.

Cheng Liren and Yue Zifang were the only two Chinese prisoners who settled in Argentina. Cheng, the child of a large landlord and businessman in Guizhou, graduated from the Nationalist Central Police Academy and worked briefly as a police officer. When the Communists took power and began a bloody purge of former Nationalists, he, in desperation, enlisted in the PLA to escape imminent local persecution. ${ }^{40}$ Yue's archival document is lacking, but it was widely known among fellow pows that he publicly executed his own father, a Nationalist county mayor, during a Communist-orchestrated trial in early 1950. Perhaps he was too ashamed to relocate to Nationalist Taiwan. ${ }^{41}$ Unsurprisingly, he chose an undetermined neutral nation, where no one knew his past. Not long after arriving in Argentina, he moved to Peru and vanished. ${ }^{42}$

Finally, two Chinese prisoners remained in India. In July 1958, Korean Pow Han P'yo-ku went to the U.S. embassy in New Delhi to ask for help to relocate to Mexico. He reported the status of eleven prisoners remaining in India, including two Chinese. The 29-year-old Hoc Wa Sheong married an Indian woman and became a truck driver in Bangalore. Heo Chou, a 33-year-old Chinese Muslim, wished to emigrate to Pakistan, but "his mind was slipping" and was "kept in room separate from Koreans at National Stadium New Delhi." ${ }^{3}$ No further information is available about these two men.

This introduction and the three articles that follow are the first products of the collaborative investigative work among the authors, but they already offer fascinating new perspectives on the Korean War and beyond. By examining these Pows' pre-war experiences in Manchuria, China, colonial and post-liberation Korea, and their postwar years in India and Latin America, their research

39 Leonardo Barbosa, "55 Remnants of Conflict: The Korean War Prisoners Who Chose Brazil," 23 May 2019, Sino-NK, https://sinonk.com/2019/o5/23/55-remnants-of-conflict-the-koreanwar-prisoners-who-chose-brazil (accessed 1 June 2020); Leonardo Barbosa, “From Batallón Colombia to Sixty-nine Ex-POWs: The Unforeseen Impact of Latin America in the Korean War," unpublished Master of Philosophy thesis, Hong Kong University of Science and Technology, forthcoming 2021.

40 Chang, The Hijacked War, pp. 59-6o.

41 Author's interview with Liu Chunjian, 26 March 2015, Jilong, Taiwan.

42 Author's interview with Cheng Liren, 14-17 October 2014, Buenos Aires, Argentina.

43 Embassy New Delhi to Department of State, 24 July 1958, 695A.0024/7-2458, RG 59, NAII. 
extends the temporal boundary of the inquiry on the Korean War before and after it broke out on 25June 1950 and beyond 27 July 1953 when the conflict ended with the signing of the armistice agreement. They expand the spatial boundary of the study beyond the Korean Peninsula to explore the complex interactions among various stakeholders at the supranational, international, and personal levels. Using in-depth oral history interviews with several surviving Korean and Chinese former prisoners, private papers, and archival documents from multiple nations, their research offers unprecedentedly intimate and personal accounts of the conflict and their impact on ordinary people not just in the Korean War, but during World War II, the Chinese Civil War, pre-war North Korea, and the larger Cold War as well. These papers also open up other exciting research possibilities on topics such as India's relations with China, North Korea, and South Korea, Latin America and Asia, in addition to studies of the roles of the neutral nations, the Non-Alignment movement, and more specifically, India in the Cold War. This new research holds the promise of making Korean War studies truly transnational and global and at the same time personal and grassroots.

\section{Selected Bibliography}

\section{Primary Sources}

Author and Lee Peihua's interview. Kim Kwan-ok, 15 October 2014, Buenos Aires Argentina. Author and Lee Sunwoo's interview. Kim Kwan-ok, 6 February, 2017, São Paulo, Brazil. Author's Interview. Cheng Liren, 14-17 October 2014. Buenos Aires, Argentina.

Author's Interview. Liu Chunjian, 26 March 2015, Jilong, Taiwan.

Clark, Mark W. From the Danube to the Yalu. New York: Harper, 1954.

Jiefang Ribao [Liberation Daily], 27 August 1942, p. 2.

Neibu Cankao [Internal Reference], 5 June 1951, pp. 84-85.

New York Times, 5 February 1954, p. 4.

United Nations Archives. New York, NY.

U.S. Army Military History Office. The Handling of Prisoners of War During the Korean War. San Francisco, CA: Headquarters, U.S. Army, Pacific, 196o.

U.S. Department of State. Records of the U.S. Department of State. Record Group 59. National Archives, College Park, MD.

Washington Post, 12 June 1952, p. 6.

\section{Secondary Sources}

Barbosa, Leonardo. "From Batallon Colombia to Sixty-nine Ex-POWs: The Unforeseen Impact of Latin America in the Korean War." Unpublished Master of Philosophy Thesis. Hong Kong University of Science and Technology, Hong Kong, forthcoming 2021. 
Barbosa, Leonardo. "55 Remnants of Conflict: The Korean War Prisoners Who Chose Brazil,” 23 May 2019, Sino-NK, https://sinonk.com/2019/o5/23/55-remnants-ofconflict-the-korean-war-prisoners-who-chose-brazil (accessed 1 June 2020).

Barris, Ted. Deadlock in Korea: Canadians at War, 1950-1953. Toronto: Macmillan Canada, 1999.

Bernstein, Barton J. "The Struggle over the Korean Armistice: Prisoners of Repatriation.” In Child of Conflict: The Korean-American Relationship, 1945-1953. Cumings Bruce, Ed., 261-307. Seattle: University of Washington Press, 1983.

Bradbury, William C., Samuel M. Meyers, and Albert D. Biderman, Eds. Mass Behavior in Battle and Captivity: The Communist Soldier in the Korean War. Chicago: University of Chicago Press, 1968.

Chang, David Cheng. The Hijacked War: The Story of Chinese POWs in the Korean War. Stanford, CA: Stanford University Press, 2020.

Cumings, Bruce. The Korean War: A History. New York: Modern Library, 2010.

Foot, Rosemary. A Substitute for Victory: The Politics of Peacemaking at the Korean Armistice Talks. Ithaca, NY: Cornell University Press, 1990.

Hermes, Walter G. Truce Tent and Fighting Front. Washington, DC: U.S. Government Printing Office, 1966.

Jager, Sheila Miyoshi. Brothers at War: The Unending Conflict in Korea. New York: Norton, 2013.

Kim, Donggil. "The Chinese Civil War and the Ethnogenesis of the Korean Minority in Northeast China." Chinese Historical Review 21, No. 2 (November 2014): 121-42.

Kim, Monica. Interrogation Rooms of The Korean War: The Untold History. Princeton, NJ: Princeton University Press, 2019.

Lee Sun-woo, "Han'gukchŏnjaenggi Chungnipkuk Sŏnt'aek P'oroŭi Palsaenggwa Sŏnggyŏk" ["The Characteristics and Arrangement of the Prisoners of War Who Chose to Go to Neutral Countries During the Korean War"], Yŏksa wa Hyŏnsil [Quarterly Review of Korean History], no. 90 (December 2013): 317-58.

MacDonald, Callum A. Korea: The War Before Vietnam. New York: Free Press, 1986.

Morris-Suzuki, Tessa. "Prisoner Number 6oo,oor: Rethinking Japan, China, and the Korean War 1950-1953." Journal of Asian Studies 74, no. 2 (May 2015): 411-32.

Prasad, S. N. History of the Custodian Force (India) in Korea, 1953-54. New Delhi, India: Historical Section, Ministry of Defence, 1976.

Stueck, William. The Korean War: An International History. Princeton, NJ: Princeton University Press, 1995.

Thimayya, Kodendera S. Experiment in Neutrality. New Delhi: Vision Books, 1981. Toland, John. In Mortal Combat: Korea, 1950-1953. New York: William Morrow, 1991. Young, Charles S. Name, Rank, and Serial Number: Exploiting Korean War POWs at Home and Abroad. New York: Oxford University Press, 2014. 